\title{
PENDEKATAN TAKTIS DITERAPKAN DALAM PEMBELAJARAN AKTIVITAS PERMAINAN BOLA VOLI DI SD NEGERI 1 TUK KARANG SUWUNG KECAMATAN LEMAH ABANG KABUPATEN CIREBON
}

\author{
Rahmat rahmat $^{1)}$, dan Anggi Anggara ${ }^{2)}$ \\ ${ }^{1}$ Prodi Pendidikan Jasmani Kesehatan dan Rekreasi, Universitas Islam Al-Ihya \\ Kuningan \\ ${ }^{2}$ Prodi Pendidikan Jasmani Kesehatan dan Rekreasi, Universitas Islam Al-Ihya \\ Kuningan \\ e-mail: rahmat.aj75@yahoo.com ${ }^{1}$, anggianggara2701@gmail.com ${ }^{2}$
}

\begin{abstract}
Abstrak
Dilingkungan persekolahan permainan bolavoli merupakan salah satu aktivitas pembelajaran Pendidikan Jasmani, yaitu: dalam ruang lingkup materi permainan dan olahraga. Dalam Peraturan Menteri Pendidikan Nasional Nomor 22 Tahun 2006 tentang Standar Isi untuk satuan pendidikan dasar dan menengah (2006:195). Dengan dimasukannya permainan bolavoli ke dalam kurikulum Pendidikan Jasmani, sebagai salah satu aktivitas pembelajaran pendidikan jasmani maka guru dan sekolah berkewajiban untuk menjadikan permainan bolavoli menjadi salah satu aktivitas pembelajaran pendidikan jasmani. Selanjutnya dalam Peraturan Menteri Pendidikan Nasional dijelaskan bahwa standar kompetensi yang di ajarkan guru kepada siswa setelah mengikuti pelajaran tersebut adalah sebagai berikut : Mempraktikkan gerakan dasar ke dalam permainan sederhana dan olahraga serta dalam nilai-nilai yang terkandung di dalamnya, yang terdiri dari tiga kompetensi dasar, yaitu (1) Mempraktikkan permainan bola kecil sederhana dengan peraturan yang dimodifikasi, serta nilai kerjasama tim, sportivitas, dan kejujuran; (2) Mempraktikkan gerak dasar atletik sederhana, serta semangat, percaya diri dan disiplin; (3) Mempraktikkan gerak dasar permainan bola besar sederhana dengan peraturan yang dimodifikasi, serta nilai kerjasama, sportivitas dan kejujuran. Masalah dan batasan masalah, maka masalah yang dikaji dalam penelitian ini dapat dirumuskan sebagai berikut: 1) Bagaiaman pola pembelajarn dengan menggunakan pendekatan taktis pada siswa di SD Negeri 1 Tuk Karang Suwung?. 2) Bagaimana pendekatan taktis diterapkan dalam pembelajaran aktivitas permainan bolavoli di SD Negeri 1 Tuk Karang Suwung?. 3) tujuan penelitian ini adalah dalam rangka memperbaiki dan meningkatkan mutu atau kualitas pembelajaran permainan bolavoli di SD Negeri 1 Tuk Karang Suwung kec.Lemah Abang Kab.Cirebon. Kesimpulan pembahasan pendekatan taktis dalam proses pembelajaran keterampilan bermain adalah sebagai berikut : 1) Melalui latihan yang mirip dengan permainan yang sesungguhnya, minat dan kegembiraan siswa akan meningkat. 2) Peningkatan pengetahuan taktik, penting bagi siswa untuk menjaga konsistensi keberhasilan pelaksanaan keterampilan gerak teknik yang sudah dimiliki. 3) Memperdalam pemahaman bermain dan meningkatkan kemampuan pemahaman secara lebih efektif dari penampilan dalam satu permainan ke dalam permainan lainnya.
\end{abstract}

Kata kunci: Pendekatan Taktis, Pembelajaran, Permainan Bola Voli 


\begin{abstract}
The environment of volleyball game schooling is one of the physical education learning activities, namely: within the scope of the game and sports material. In the Minister of National Education Regulation No. 22/2006 concerning Content Standards for primary and secondary education units (2006: 195). With the inclusion of volleyball games in the Physical Education curriculum, as one of the physical education learning activities, teachers and schools are obliged to make volleyball games one of the physical education learning activities. Furthermore, in the Minister of National Education Regulation it is explained that the competency standards taught by teachers to students after attending the lessons are as follows: Practicing basic movements in simple games and sports as well as in the values contained therein, which consists of three basic competencies, namely (1) Practicing simple little ball games with modified rules, and the value of teamwork, sportsmanship, and honesty; (2) Practicing simple athletic basic movements, as well as enthusiasm, self-confidence and discipline; (3) Practicing the basic motion of a simple big ball game with modified rules, as well as the value of cooperation, sportsmanship and honesty. Problems and limitations of the problem, the problems examined in this study can be formulated as follows: 1) How are learning patterns using a tactical approach to students at SD Negeri 1 Tuk Karang Suwung ?. 2) How is the tactical approach applied in learning volleyball game activities at SD Negeri 1 Tuk Karang Suwung ?. 3) the purpose of this study is in order to improve and improve the quality or quality of learning volleyball games at SD Negeri 1 Tuk Karang Suwung kec.Lemah Abang Kab. Cirebon. The conclusion of the discussion of tactical approach in the learning process of playing skills is as follows: 1) Through exercises that are similar to the real game, students' interest and excitement will increase. 2) Increased knowledge of tactics, it is important for students to maintain consistency in the successful implementation of the technical movement skills they have. 3) Deepening understanding of play and increasing the ability to understand more effectively from the appearance in one game to another.
\end{abstract}

Keywords: Tactical Approaches, Learning, Volleyball Games 


\section{PENDAHULUAN}

Perkembangan olahraga permainan bola voli di masyarakat sangat pesat, terbukti dengan sering diadakan pertandingan yang pesertanya tidak hanya dari kalangan orang dewasa, tetapi anak-anak dan remaja baik pria maupun wanita. Mereka yang menyenangi olahraga permainan bolavoli sebagai ajang rekreasi, tidak akan melewatkan olahraga ini untuk mengisi waktu luang mereka sebagai pelepas beban pikiran yang menjenuhkan selama bekerja. Mereka yang memiliki bakat dan minat bermain bola voli dapat memfokuskan diri ke tingkat keterampilan yang lebih tinggi sebagai atlet untuk mencapai prestasi setinggi-tinginya. Sejalan dengan pemaparan di atas, menurut Subroto dan Yudiana dalam bukunya yang berjudul "Permainan Bola Voli" (2010:26) adalah sebagai berikut :

Tujuan orang bermain bolavoli berawal dari tujuan yang bersifat rekreatif, kemudian berkembang ke arah tujuantujuan yang lain seperti mencapai prestasi yang tertinggi, meningkatkan prestise diri atau bangsa dan Negara, memelihara dan meningkatkan kesehatan dan kebugaran jasmani, bahkan dalam konteks pendidikan kedudukan dan fungsi permainan ini adalah sebagai salah satu alat atau sarana untuk mencapai tujuan pendidikan.

Dilingkungan

persekolahan permainan bolavoli merupakan salah satu aktivitas pembelajaran Pendidikan Jasmani, yaitu: dalam ruang lingkup materi permainan dan olahraga. Dalam Peraturan Menteri Pendidikan Nasional Nomor 22 Tahun 2006 tentang Standar Isi untuk satuan pendidikan dasar dan menengah (2006:195). Dengan dimasukannya permainan bolavoli ke dalam kurikulum Pendidikan Jasmani, sebagai salah satu aktivitas pembelajaran pendidikan jasmani maka guru dan sekolah berkewajiban untuk menjadikan permainan bolavoli menjadi salah satu aktivitas pembelajaran pendidikan jasmani. Selanjutnya dalam Peraturan Menteri Pendidikan Nasional dijelaskan bahwa standar kompetensi yang di ajarkan guru kepada siswa setelah mengikuti pelajaran tersebut adalah sebagai berikut :

Mempraktikkan gerakan dasar ke dalam permainan sederhana dan olahraga serta dalam nilai-nilai yang terkandung di dalamnya, yang terdiri dari tiga kompetensi dasar, yaitu (1) Mempraktikkan permainan bola kecil sederhana dengan peraturan yang dimodifikasi, serta nilai kerjasama tim, sportivitas, dan kejujuran; Mempraktikkan gerak dasar atletik sederhana, serta semangat, percaya diri dan disiplin; (3) Mempraktikkan gerak dasar permainan bola besar sederhana dengan peraturan yang dimodifikasi, serta nilai kerjasama, sportivitas dan kejujuran.

Merujuk kepada rumusan standar kopetensi di atas, maka standar kompetensi yang harus dicapai oleh aktivitas pembelajaran permainan bolavoli dapat dirumuskan sebagai berikut, "Mempraktikkan gerakan dasar ke dalam permainan bolavoli sederhana (modifikasi) serta nilai-nilai yang terkandung didalamnya, seperti kerjasama, sportivitas dan kejujuran".

Merujuk kepada Kurikulum Tingkat Satuan Pendidikan (KTSP) 2006 dilingkungan Sekolah Dasar (SD) permainan bolavoli mulai dapat diajarkan pada kelas IV dalam ruang lingkup materi permainan dan olahraga. Permainan bolavoli menjadi materi pembelajaran di SD yang kemudian disebut sebagai permainan bolavoli.

Permasalahan umum yang sering terjadi dalam praktik pembelajaran aktivitas permainan bolavoli diantaranya ketersediaan sarana dan prasarana, 
peralatan, karakteristik siswa dan kemampuan siswa. Sarana dan Prasarana Yang dimaksud dengan permasalahan sarana dan prasarana dalam penelitian ini adalah rasio antara jumlah siswa dengan sarana dan prasarana yang kurang. Ketersediaan sarana dan prasarana dibeberapa Sekolah Dasar masih dikatakan sangat mengkhawatirkan. Keterbatasan baik dari sarana maupun prasarana dapat terlihat dengan lahan yang begitu sempit untuk pelaksanaan pembelajaran Penjas. Terbukti dengan ditemukannya lapangan yang luasnya hanya sebesar lapangan bulutangkis di beberapa Sekolah Dasar, tidak adanya sporthall, dan tidak adanya ruang olahraga. Namun ada juga yang ukuran lapangan bolavolinya untuk orang dewasa yang berukuran $18 \mathrm{~m} \quad \mathrm{x} \quad 9 \mathrm{~m}$ tidak disesuaikan dengan siswa Sekolah Dasar yaitu menggunakan lapangan bolavoli mini (12 m x $6 \mathrm{~m})$. Dijelaskan dalam naskah lokakaraya prototype sarana dan prasarana olahraga tahun 1978-1979, bahwa Standar umum prasarana sekolah olahraga dan kesehatan, "...jumlah kelas 6-10 kelas kebutuhan prasarana olahraganya $1.400 \quad \mathrm{M} 2$ dengan jenis prasarana olahraga yang tersedia adalah lapangan olahraga serbaguna (15 x 30) M2, atletik (500 M2), dan bangsal terbuka (12,5 x 25) M2 tinggi 6 M..." (Depdiknas, 2003:24)

Peralatan. Yang dimaksud permasalahan keterbatasan peralatan dalam penelitian ini adalah rasio jumlah siswa dengan peralatan. Bola yang digunakan adalah bola ukuran dewasa yang dianggap keras oleh siswa Sekolah Dasar tidak menggunakan bolavoli mini (ukuran nomor 4) yang ukurannya lebih kecil dan ringan. Tinggi net yang juga untuk ukuran orang dewasa (putra 2,43 m dan putrid 2,24 m) tidak menggunakan peraturan permainan bolavoli mini dengan ukuran tinggi net $2,10 \mathrm{~m}$ untuk putra dan 2,00 m untuk putri dan ada juga guru sebagai guru pengajar olahraga yang jarang membawa stopwatch dan peluit. Pada kenyataannya dengan bola satu buah dan lapangan bolavoli yang ada hanya satu buah, siswa yang tidak mendapat giliran bermain bolavoli hanya berdiam diri, mengobrol dengan teman, bermain permainan lain, dan pergi ke warung untuk jajan.

Karakteristik Siswa. Siswa yang begitu banyak dengan tingkat kecerdasan yang berbeda-beda, menjadikan guru Penjas harus lebih kreatif dan inovatif untuk menjaga waktu aktif belajar siswa seoptimal mungkin. Tingkat kecerdasan siswa yang berbeda-beda akan terlihat dengan jelas pada saat pembelajaran permainan bolavoli, seperti adanya perbedaan pemahaman siswa antara satu dengan yang lainnya mengenai konsep dasar permainan bolavoli. Siswa memiliki tingkat pemahaman yang berbeda-beda terbukti dengan ditemukannya terdapat perbedaan berbagai teknik dasar permainan bolavoli yang dilakukan siswa. Bisa dilihat dari ada yang senang dengan permainan bolavoli dan ada juga yang kurang menyukainya. Sebagai contoh pada siswa di Sekolah Dasar ada yang aktif dalam mengikuti aktivitas permainan bolavoli dan ada siswa yang hanya diam saja. Namun demikian siswa yang kurang aktif hanya melihat dan malah melakukan aktivitas diluar permainan bolavoli, biasanya siswa mengobrol, jajan, dll.

Keterampilan/Kemampuan Siswa. Siswa yang begitu banyak dengan tingkat kecerdasan yang berbeda-beda. Tingkat kecerdasan siswa yang berbeda- beda akan terlihat dengan jelas pada saat pembelajaran permainan bolavoli, seperti adanya perbedaan pemahaman siswa antara satu dengan yang lainnya mengenai konsep dasar passing. Siswa memiliki tingkat pemahaman yang berbeda-beda terbukti dengan ditemukannya terdapat perbedaan berbagai teknik dasar passing yang dilakukan siswa. Dengan kurangnya 
penguasaan materi gerak dasar permainan bolavoli yang dimiliki oleh guru penjas di sekolah tersebut, maka siswa mendapatkan cara-cara sendiri untuk melakukan gerak dasar permainan bolavoli dari hasil pengalaman mereka diluar sekolah.

Secara khusus permasalahan yang terjadi dalam Proses Belajar Mengajar permainan bolavoli di SD Negeri 1 Tuk Karang Suwung adalah Berdasarkan hasil pengamatan penulis bahwa sekolah tersebut memiliki fasilitas satu buah lapangan bolavoli ukuran dewasa (18 $\mathrm{m} \mathrm{X}$ $9 \mathrm{~m}$ ) dan area taman bermain yang cukup luas $( \pm 8 \mathrm{~m} \quad \mathrm{X} \quad 8 \mathrm{~m})$. Peralatan dan perlengkapan permainan bolavoli, yaitu satu buah bolavoli yang rusak yang tidak dapat dipergunakan dan satu buah net. Lapangan yang berdebu yang dapat merusak pernapasan serta terkadang menjadi licin karena kerikil kecil yang berserakan dimana-mana. Dengan satu buah lapangan bolavoli dan area bermain yang cukup luas. Bola yang digunakan adalah bola ukuran dewasa dan hanya ada satu buah bola yang dianggap keras oleh siswa SD. Lapangan bola voli merupakan lapangan untuk orang dewasa yang berukuran $18 \mathrm{~m}$ x $9 \mathrm{~m}$. Tinggi net yang juga untuk ukuran orang dewasa (putra 2,43 $\mathrm{m}$ dan putrid 2,24 m).

Dijelaskan dalam naskah lokakaraya prototype sarana dan prasarana olahraga tahun 1978-1979, bahwa Standar umum prasarana sekolah olahraga dan kesehatan, "...jumlah kelas 6-10 kelas kebutuhan prasarana olahraganya $1.400 \mathrm{M} 2$ dengan jenis prasarana olahraga yang tersedia adalah lapangan olahraga serbaguna (15 x 30) M2, atletik (500 M2), dan bangsal terbuka $(12,5$ x 25$)$ M2 tinggi 6 M..." (Depdikas, 2003:24).

Perhatian dari pihak sekolah terhadap perbaikan fasilitas untuk meningkatkan mutu pendidikan khususnya dalam pembelajaran permainan bolavoli harus disesuaikan dengan alokasi dana yang ada di sekolah tersebut. Pembelajaran permainan bolavoli dengan lapangan yang seadanya dan bola satu buah menurut pihak sekolah sudah cukup untuk pembelajaran Penjas. Menurut pengakuan dari beberapa SD khususnya di Kecamatan Pabuaran bahwa alokasi dana yang ada sangatlah terbatas untuk melengkapi sarana dan prasarana Penjas khususnya untuk pembelajaran permainan bolavoli.

Berdasarkan pengamatan dalam proses pembelajaran permainan bolavoli di SD Negeri 1 Tuk Karang Suwung, siswa lebih banyak menunggu giliran mendapatkan bola ketika guru Penjas menginstruksikan kepada siswa untuk bermain bolavoli tanpa menjelaskan atau memberikan materi apa yang akan diajarkan. Siswa hanya disuruh langsung bermain bolavoli dalam waktu 2 x 30 menit sesuai dengan jadwal mata pelajaran Pendidikan Jasmani, Olahraga, dan Kesehatan. Pada kenyataannya dengan bola satu buah dan lapangan bolavoli yang ada hanya satu buah, siswa yang tidak mendapat giliran bermain bolavoli hanya berdiam diri, mengobrol dengan teman, bermain permainan lain, dan pergi ke warung untuk jajan. Terkadang guru Penjas menggunakan metode yang membuat anak menjadi menunggu terlalu lama untuk mendapat kesempatan mendapatkan bola. Siswa yang tidak mendapat bola, mereka akan menunggu dan berdiam diri atau ngobrol dengan temannya untuk mendapatkan gilirannya. Hal-hal tersebut diatas akan mengakibatkan sasaran dari konsep Pendidikan Jasmani dengan memanfaatkan waktu aktif belajar yang optimal menjadi tidak tercapai.

Pihak sekolah yang telah berusaha meningkatkan mutu pembelajaran Pendidikan Jasmani, Olahraga, dan Kesehatan mengenai masalah yang terjadi di sekolah tersebut khususnya dalam penyediaan sarana dan prasarana yang 
memadai untuk pembelajaran permainan bolavoli. Akan tetapi menurut pihak sekolah yang menjadi kendala adalah alokasi dana untuk itu sangat terbatas. Berdasarkan penjelaskan Kepala Sekolah SD Negeri 1 Tuk Karang Suwung yang baru menjabat 2 tahun, bahwa "adanya peningkatan terhadap perbaikan prasarana yang dulunya tidak ada sama sekali dan sekarang menjadi lebih baik.

Penggunaan model pendekatan taktis dalam pembelajaran olahraga bolavoli (Penelitian Tindakan Kelas) diharapkan mampu meminimalisir masalah- masalah yang timbul dalam pelaksanaan pembelajaran aktivitas permainan bolavoli di SD Negeri 1 Tuk Karang Suwung Kec.Lemah Abang, Cirebon, baik yang bersifat internal maupun eksternal. Faktor internal adalah hal-hal yang menyangkut pada diri siswa itu sendiri, yaitu faktor jasmaniah (kesehatan dan cacat tubuh), hal ini sangat berkaitan dengan keterampilan teknik dan bermain aktivitas permainan bolavoli, karena kemampuan fisik dan kesehatan pada diri siswa itu sendiri akan menopang keberhasilan siswa tersebut dalam intensitas dan aktivitas pembelajaran siswa, selain itu juga kesempurnaan fisik akan lebih membantu siswa itu tersebut dalam melakukan olahraga, dibandingkan dengan siswa yang kurang sempurna keadaan fisiknya, seperti kekurangan anggota badan yang diakibatkan bawaan (haritage) atau turunan dari orang tua siswa tersebut atau yang diakibatkan oleh suatu kecelakaan dimasa lalu.

Berdasarkan pada karakteristik kesulitan yang dihadapi dalam proses pembelajaran aktivitas permainan bolavoli, serta kurangnya motivasi dan pemahaman gerak siswa tentang bermain dan belajar aktivitas permainan bolavoli yang mendorong penulis untuk melakukan perubahan melalui Model Pendekatan Taktis dalam mengembangkan keterampilan gerakan dasar dan keterampilan yang dimiliki siswa sebelum masuk ke dalam proses pembelajaran, dalam hal ini penulis menggunakan metode Penelitian Tindakan Kelas yang merupakan terjemahan dari Classroom Action Research, yang dilakukan oleh guru atau peneliti di dalam kelasnya sendiri, dengan tujuan untuk memperbaiki kinerjanya sebagai guru.

Dengan diadakannya penelitian ini penulis berharap agar keterampilan gerakan dasar dan keterampilan bermain siswa lebih meningkat dan siswa lebih tertarik terhadap pembelajaran permainan bolavoli. Selain dapat menyalurkan dan mengembangkan keterampilan gerakan dasar dan keterampilan aktivitas permainan bolavoli, penulis berharap siswa dapat menerapkannya di dalam permainan yang sebenarnya.

\section{BAHAN DAN METODE/ METODOLOGI}

Setelah proses penelitian berlangsung terdapat pemfokusan masalah di sekitar penerapan pendekatan taktis dalam pembelajaran aktivitas permainan bolavoli. Melalui pemfokusan permasalahan ini maka tujuan operasional dari penelitian ini adalah untuk mengembangkan model-model pembelajaran aktivitas permainan bolavoli melalui pendekatan taktis yang dapat diterapkan di SD Negeri 1 Tuk Karang Suwung terutama untuk kelas IV.

Metode yang digunakan dalam penelitian ini adalah penelitian tindakan kelas (classroom action research), penelitian yang dilakukan pada sebuah kelas untuk mengetahui akibat tindakan yang diterapkan pada suatu subyek penelitian di kelas.

\section{Langkah-langkah Penelitian}

Merujuk kepada langkah-langkah penelitian yang di bahas secara mendalam di dalam BAB II, maka dalam penelitian ini, langkah-langkah yang dilakukan adalah mengidentifikasi masalah yang 
terjadi di dalam sekolah yang bersangkutan yang terkait dengan fokus penelitian yang meliputi masalah-masalah yang terkait dengan masalah tujuan pembelajaran, materi pembelajaran, strategi pembelajaran, dan evaluasi hasil belajar.

Berdasarkan masalah yang teridentifikasi, selanjutnya diikuti observasi awal, perencanaan, pelaksanaan tindakan (aksi), refleksi, dan perencanaan ulang yang dapat diuraikan sebagai berikut :

\section{Observasi Awal}

Observasi dilakukan pada awal peneliti turun kelapangan. Fokus masalah yang akan diteliti atau diobservasi dengan cara dokumentasi. Maksud observasi adalah mengidentifikasi permasalahanpermasalahan pembelajaran yang terkait dengan fokus masalah yang diteliti. Observasi awal dilakukan terhadap dokumen RPP (Rencana Program Pembelajaran) yang dibuat oleh guru, melihat relevansi antara pelaksanaan pembelajaran dengan RPP yang dibuat, melihat relevansi antara model/ metode/ strategi/ pendekatan yang direncanakan dengan pelaksanaannya, kemudian melihat hasil belajar untuk mengevaluasi proses pembelajaran.

Berdasarkan masalah-masalah pembelajaran yang teridentifikasi pada tahap observasi awal, selanjutnya peneliti membuat suatu perencanaan perbaikan pembelajaran. Semua informasi yang diperoleh dari hasil observasi awal tersebut dijadikan landasan untuk membuat suatu perencanaan pembelajaran untuk tindakan selanjutnya.

2. Perencanaan (planning)

Berdasarkan hasil observasi tersebut di atas, semua permasalahan hasil observasi awal dijadikan landasan untuk membuat suatu perencanaan tindakan. Perencanaan tindakan berikutnya dibuat berdasarkan hasil refleksi dari tindakan pelaksanaan pertama begitu seterusnya sampai permasalahan terpecahkan.

3. Pelaksanaan Tindakan (action)

Setelah perencanaan pertama dibuat, selanjutnya dilaksanakan tindakan pertama. Sesuai dengan langkah-langkah dalam penelitian tindakan kelas bahwa hasil tindakan pertama harus dilakukan kegiatan refleksi. Hasil refleksi dijadikan sebagai dasar untuk membuat perencanaan tindakan kedua dan pelaksanaan tindakan kedua

3. Refleksi (reflection)

Merefleksikan permasalahan yang sudah teridentifikasi pada pemecahan masalah sebelum perencanaan dibuat atau mengidentifikasi masalah-masalah yang baru muncul pada saat pembelajaran itu diluar apa yang sudah direncanakan. Hasil refleksi ini selanjutnya dibuatkan suatu perencanaan kedua untuk tindakantindakan perbaikan pertama.

\section{Teknik Pengumpulan Data}

1. Sumber data :
a. Siswa-siswi kelas IV SD Negeri 1 Tuk Karang Suwung yang mengikuti pembelajaran aktivitas permainan bolavoli dengan menggunakan pendekatan taktis.
b. Guru/peneliti yang mengajar permainan bolavoli menggunakan pendekatan taktis.
c. Lingkungan sekolah SD Negeri 1 Tuk Karang Suwung yang dijadikan tempat penelitian.

2. Jenis data : data yang didapatkan adalah data kualitatif yang terdiri dari :
a. RPP
(Rencana
Program
Pembelajaran)
b. Hasil observasi terhadap pelaksanaan pembelajaran
c. Catatan lapangan
d. Dokumentasi (photo/camera)

\section{Cara pengambilan data}

1. Data hasil belajar didapat dari RPP.

2. Data tentang situasi belajar mengajar pada saat pelaksanaannya tindakan 
diambil dengan menggunakan catatan lapangan.

3. Data tentang keterampilan antara perencanaan dengan pelaksanaan didapat dari RPP dan catatan lapangan.

4. Data dokumentasi dilakukan pada proses belajar mengajar berlangsung.

\section{Teknik Analisa Data}

Meleong (2002:110) mengemukakan "Analisis data adalah proses mengorganisasikan dan mengurutkan data kedalam pola, kategori dan satuan uraian dasar sehingga dapat dikemukakan tema dan dapat dirumuskan hipotesis kerja seperti yang disarankan data".

Proses analisis dimulai dari awal sampai akhir pelaksanaan tindakan. Data yang terkumpul dapat dianalasis dari tahap orientasi sampai tahap akhir dalam pelaksanaan tindakan dengan disesuaikan pada karakteristik, fokus masalah serta tujuan.

Setelah data terkumpul dianalisis dengan menggunakan teknik kualitatif supaya diperoleh data yang sesuai dengan fokus masalah. Data tersebut meliputi perkataan, tindakan, peristiwa yang diamati (observasi) selama proses pelaksanaan pembelajaran pendidikan jasmani berlangsung. Secara garis besar analisis data dilakukan dengan langkahlangkah sebagai berikut :

1. Menelaah seluruh data yang dikumpulkan. Penelaahan dilakukan dengan cara menganalisis, mensistensis, memaknai, menerangkan dan menyimpulkan.

2. Mereduksi data yang di dalamnya melibatkan kegiatan pengkatagorian dan mengklasifikasikan. Hasil yang diperoleh berupa pola-pola dan kecenderungan-kecenderungan yang berlaku dalam pelaksanaan pembelajaran pendidikan jasmani.

\section{HASIL DAN PEMBAHASAN}

Berdasarkan hasil temuan peneliti menerapkan pembelajaran pendekatan taktis dalam pembelajaran aktivitas permainan bolavoli di SDN I Tuk Karang Suwungadalah sebagai berikut :

1. Guru belum mampu menyajikan model pembelajaran pendidikan jasmani dalam bentuk permainan secara sistematis.

2. Minat dam motivasi siswa dalam mengikuti kegiatan pembelajaran pendidikan jasmani masih rendah.

3. Guru harus bisa mengawasi seluruh siswa, apabila terjadi masalah dalam setiap kelompok, maka guru harus bisa memberikan arahan.

4. Permasalah yang terjadi pada pelakanaan siklus 1 dan siklus 2 sudah dapat dipecahkan dengan penerapan pembelajaran pendekatan taktis.

Oleh karena itu, pengamat meneliti terhadap penerapan pendekatan taktis dalam pembelajaran aktivitas permainan bolavoli di akhiri. Ketika murid melakukan kegiatan aktivitas permainan dengan menggunakan pendekatan taktis siswa dapat meningkatkan pemahamannya sendiri mengenai tugas gerak dengan cara berkontribusi untuk meningkatkan praktek ketika melakukan permainan dengan menggunakan pendekatan taktis. Pendekatan taktis memiliki potensi untuk meningkatkan waktu belajar atau berlatih siswa dalam proses pembelajaran selain itu siswa belajar disiplin, kerjasama, berkomunikasi dan menumbuh kembangkan rasa percaya diri murid dalam pembelajaran pendidikan jasmani.

\section{KESIMPULAN}

Secara keseluruhan dengan diberikan model latihan, kesalahan siswa dalam menggunakan keterampilan taktis dapat diminimalkan serta kemampuan mereka dalam menggunakan pemahaman polapola permainan bolavoli menjadi lebih baik dan meningkat.

Hasil penelitian menunjukkan bahwa pemahaman pola-pola permainan bolavoli 
melalui pembelajaran pendekatan taktis terdapat perbandingan antara siswa yang berkemampuan awal tinggi dan siswa yang berkemampuan rendah. Dengan demikian, pemahaman pola-pola permainan bolavoli tersebut dapat digunakan sebagai alternatif untuk memilih dan memantapkan pemahaman yang digunakan dalam mengajar permainan bolavoli.

Jika dilihat dan karakteristik klasifikasi pemahaman siswa kelas IV, karakteristik pembelajaran aktivitas permainan bolavoli termasuk ke dalam karakteristik keterampilan bolavoli melalui pendekatan taktis. Oleh karena itu, pengamatan peneliti terhadap pelaksanaan proses pembelajaran permainan di SDN I Tuk Karang Suwung, ditemukan masalahmasalah yakni ketidakseimbangan antara penguasaan keterampilan teknik dengan proses pembelajaran yang menekankan pada peningkatan performa atau penampilan bermain. Sebagai kesimpulan pembahasan pendekatan taktis dalam proses pembelajaran keterampilan bermain adalah sebagai berikut :

1. Melalui latihan yang mirip dengan permainan yang sesungguhnya, minat dan kegembiraan siswa akan meningkat.

2. Peningkatan pengetahuan taktik, penting bagi siswa untuk menjaga konsistensi keberhasilan pelaksanaan keterampilan gerak teknik yang sudah dimiliki.

3. Memperdalam pemahaman bermain dan meningkatkan kemampuan pemahaman secara lebih efektif dari penampilan dalam satu permainan ke dalam permainan lainnya.

\section{DAFTAR PUSTAKA}

Depdiknas. (2003). Kurikulum 2004. Jakarta: Depdiknas.

Lutan Rusli. (1998). Asas-Asas Pendidikan Jasmani Pendidikan Gerak di Sekolah Dasar. Jakarta:

$\begin{array}{lrr}\text { Depdiknas } & \text { Dirjen } & \text { Dikdasmen } \\ \text { Kerjasama } & \text { dengan } & \text { Dirjen } \\ \text { Oleharaga. } & & \end{array}$

Angga (1986:13), Teknik Dasar dan

Kombinasi Bola Voli. Bandung.

FPOK IKIP Bandung.

Bonnie Robison (1991:12), Bimbingan

Petunjuk dan Teknik Bermai Bola

Voli. Jakarta CV. Dahara Prize.

BSNP (2006:195) Model Kurikulum Tingkat

Satuan Pendidikan. Depdiknas.

Mahendra Agus. (2007). Teori Belajar

Mengajar Motorik. Bandung: FPOK

UPI. Nasution. (1996). Berbagai

Pendekatan Dalam Proses Belajar

dan Mengajar. Jakarta: Bumi Aksara.

Sagala Syaiful. (2010). Kosep dan Makna

Pembelajaran (Cet. 8). Bandung: CV

Alfabeta.

Sanjaya Wina. (2006). Strategi

Pembelajaran Berorientasi Standar

Proses Pendidikan (Ed. 1 Cet. 6).

Jakarta: Kencana Prenada Media

Group.

Seba Lauren dan Hendrayana Yudi. (2005).

Perencanaan Pengajaran Pendidikan Jasmani. Bandung: FPOK UPI.

Subroto Toto dan Yudiana Yunyun. (2010). Modul Permainan Bola Voli. Bandung: FPOK UPI.

Subroto (2001) Pembelajaran

Keterampilan dan Konsep Olahraga

di Sekolah Dasar. Depdiknas. Jakarta

Sudjana Nana. (2000). Penelitian dan

Penilaian Pendidikan. Bandung: Sinar

Baru Algensindo.

Suherman Adang. (1998). Revitalisasi

Ketelantaran Pengajaran Dalam

Pendidikan Jasmani. Bandung: IKIP

Bandung Press.

Supandi. (1991). Strategi Belajar

Mengajar Pendidikan Jasmani dan

Kesehatan. 
Bandung: Depdikbud Dirjen Pendidikan Tinggi Bagian Proyek Pembinaan Tenaga Kependidikan.

Susilana Rudi, et al. (2006). Kurikulum dan Pembelajaran. Bandung: FIP UPI.
Tim Abdi Guru. (2007). Pendidikan Jasmani Olahraga dan Kesehatan Untuk SD Kelas IV. Jakarta: Erlangga.

Wiriaatmadja Rochiati. (2005). Metode Penelitian Tindakan Kelas. Bandung: Kerjasama PPS UPI Bandung dengan PT. Remaja Rosdakarya. 